\title{
2'-CHLOROPENTOSTATIN: DISCOVERY, FERMENTATION AND BIOLOGICAL ACTIVITY
}

\author{
J. B. TunAC and M. UNDERHILL \\ Warner-Lambert/Parke-Davis, Pharmaceutical Research \\ Ann Arbor, Michigan 48105, U.S.A.
}

(Received for Publication June 29, 1985)

\begin{abstract}
2'-Chloropentostatin (2-CP) is a new nucleoside antibiotic produced by Actinomadura sp. ATCC 39365. A selectively sensitive assay organism, Enterococcus faecalis PD 05045 (MIC $0.005 \mu \mathrm{g} / \mathrm{ml}$ ) was instrumental in the discovery of this compound. 2-CP is a tight-binding inhibitor of adenosine deaminase $\left(K i=1.1 \times 10^{-10} \mathrm{M}\right)$.
\end{abstract}

The nucleoside antibiotics, vidarabine and pentostatin are co-produced in the fermentation broth of the organism Streptomyces antibioticus NRRL $3238^{1}$. Vidarabine is primarily an antiviral antibiotic with marginal antitumor activity ${ }^{2)}$, while pentostatin is an inhibitor of adenosine deaminase ${ }^{3)}$. Adenosine deaminase catalyzes the deamination of vidarabine, consequently reducing its chemotherapeutic potential ${ }^{4)}$. Thus, the addition of pentostatin enhances the antiviral and antitumor activity of vidarabine $^{5)}$ by preventing its deamination to the nearly inactive ara-hypoxanthine.

In our antibiotics screening program, we have discovered 2'-chloropentostatin (2-CP), a new inhibitor of adenosine deaminase (Fig. 1), which is produced by a species of actinomycete belonging to the genus Actinomadura. The isolation and structure determination of this new antibiotic was first reported by Schaumberg et al. ${ }^{8)}$ from our laboratory. Subsequently, Ōmura et al. ${ }^{21)}$ reported the same compound.

This paper describes the assay system and biological activity of 2-CP, and the taxonomy and fermentation pattern of the organism.

\section{Materials and Methods}

\section{Assay Organism}

The test organism, Enterococcus faecalis PD 05045, an antibiotic-resistant clinical isolate, was maintained in our culture collection on Bacto-Folic acid AOAC agar medium (Difco, Detroit) containing $2.5 \mathrm{mg} /$ liter of folic acid. The inoculum was prepared by growing the culture at $37^{\circ} \mathrm{C}$ for 18 hours on Bacto-Folic acid AOAC broth medium containing $2.5 \mathrm{mg} / \mathrm{ml}$ folic acid. The culture was centrifuged and the cells resuspended in $0.85 \%$ saline to give a light transmittance of $20 \%$ at $555 \mathrm{~nm}$, (Coleman 35 Spectrophotometer, PerkinElmer).

This suspension $(1 \mathrm{ml})$ was used to inoculate $100 \mathrm{ml}$ of the molten assay medium, herein designated as chloropentostatin medium $(\mathrm{CM})$. The medium consisted of the following ingredients:

$\begin{array}{lrl}\mathrm{K}_{2} \mathrm{HPO}_{4} & 3.9 \mathrm{~g} \\ \text { Dextrose } & 25.0 & \mathrm{~g} \\ \text { Sodium citrate } \cdot 2 \mathrm{H}_{2} \mathrm{O} & 34.4 & \mathrm{~g} \\ \text { Casein hydrolysate } & 6.2 & \mathrm{~g}\end{array}$

Fig. 1. 2'-Chloropentostatin. [(R)-3-(2-Chloro-2-deoxy- $\beta$-D-ribofuranosyl)-3,6, 7,8-tetrahydroimidazo[4,5- $d][1,3]$-diazepin-8-ol].

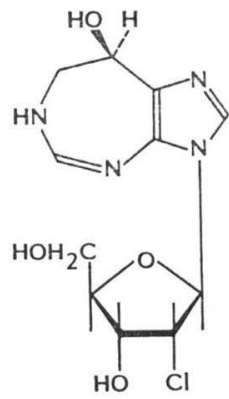




\begin{tabular}{|c|c|c|c|c|}
\hline Asparagine & 375 & $\mathrm{mg}$ & Folic acid & 500 \\
\hline L-Tryptophan & 125 & $\mathrm{mg}$ & Pyridoxine $\mathrm{HCl}$ & 2.5 \\
\hline Cysteine & 312.5 & $\mathrm{mg}$ & $\mathrm{NaCl}$ & 12.5 \\
\hline Glutathione & 0.31 & $\mathrm{mg}$ & $\mathrm{MgSO}_{4} \cdot 7 \mathrm{H}_{2} \mathrm{O}$ & 250 \\
\hline Thiamine $\mathrm{HCl}$ & 250 & $\mu \mathrm{g}$ & $\mathrm{FeSO}_{4} \cdot 7 \mathrm{H}_{2} \mathrm{O}$ & 12.5 \\
\hline Riboflavin & 625 & $\mu \mathrm{g}$ & $\mathrm{MnSO}_{4} \cdot \mathrm{H}_{2} \mathrm{O}$ & 125.0 \\
\hline $\mathrm{Ca}$ pantothenate & 500 & $\mu \mathrm{g}$ & Tween 80 & 62.5 \\
\hline Nicotinic acid & 500 & $\mu \mathrm{g}$ & Adenine sulfate & 6.25 \\
\hline$p$-Aminobenzoic acid & 625 & $\mu \mathrm{g}$ & Agar & 15.0 \\
\hline Biotin & 12.5 & $\mu \mathrm{g}$ & Distilled water & 1,000 \\
\hline
\end{tabular}

Antibiotic samples were applied onto the assay plates using $12.7 \mathrm{~mm}$ paper disks (Schleicher and Schuel). The plates were incubated at $37^{\circ} \mathrm{C}$ for $16 \sim 18$ hours, and activity was measured as inhibitory zones.

\section{Culture Characterization}

The culture was isolated from a soil sample collected in Waynesville, N.C. The soil was subsequently plated on to an agar medium consisting of the following ingredients; glycerol $3 \%$, L-asparagine $0.25 \%$, potassium chloride $0.05 \%, \mathrm{~K}_{2} \mathrm{HPO}_{4} 0.1 \%, \mathrm{MgSO}_{4} \cdot 7 \mathrm{H}_{2} \mathrm{O} 0.05 \%, \mathrm{FeSO}_{4} \cdot 7 \mathrm{H}_{2} \mathrm{O}$ $0.001 \%$, and agar $1.5 \%$.

Culture characterization was carried out following the ISP (International Streptomyces Project) procedure $^{7)}$. In addition, Waksman starch agar (WSA $)^{8)}$ and Amidex corn starch agar (ADX) ${ }^{9)}$ were used. The culture was maintained on ADX agar slants at $28^{\circ} \mathrm{C}$. Morphological and color determinations of the growth of the organism were made at weekly intervals over a three-week period. Cell wall analysis was carried out following the methods of BECKER et al. ${ }^{10)}$.

\section{Fermentation}

Stock cultures of the organism were maintained in lyophilized vials and the working culture on ADX agar slants. The microbial growth from a two-week old slant was used to inoculate a $300-\mathrm{ml}$ seed flask and incubated with shaking (New Brunswick Shaker, 5-cm throw) at $28^{\circ} \mathrm{C}$. The seed medium consisted of; $0.5 \%$ yeast hydrolysate (Amberex 1003, Amber Labs.), $0.1 \%$ glucose monohydrate, $2.4 \%$ dextrin (Amidex B411, Corn Products), $0.5 \%$ hydrolyzed peptone ( $\mathrm{N}-\mathrm{Z}$ case, HumkoSheffield), $0.3 \%$ spray dried meat solubles (Daylin Labs.), and $0.2 \% \mathrm{CaCO}_{3}$. The production of the antibiotic was carried out in 300-ml shake-flasks, 30-liter stirred-jar fermentors, and an 1,890-liter fermentor.

The production medium consisted of; $1.5 \%$ dextrin (Maltrin, Grain Processing), $1.0 \%$ lactose, $0.65 \%$ distillers solubles (Grain Processing), $0.35 \%$ peptonized milk (Humko-Sheffield), and $0.25 \%$ torula yeast (Phinelander Paper Co.). The fermentation conditions were as follows: Shake-flask, 50ml/300-ml flask, 200 rpm shaker (Model G-53, New Brunswick Shaker); 30-liter stirred-jar fermentor, 16 liters/jar, $1.0 \mathrm{vol}$ of air/vol/minute, 1,890-liter fermentor, 1,130 liters/tank, $0.375 \mathrm{vol}$ of air/vol/minute (425 liters/minute), $84 \mathrm{rpm}$. The fermentation was carried out for $4 \sim 5$ days at $33^{\circ} \mathrm{C}$.

\section{Biochemical and Biological Activity}

The ability of 2-CP to inhibit the adenosine deaminase enzyme was evaluated following the method of CHASSIN et al. ${ }^{11)}$. Briefly, the antibiotic was incubated with adenosine deaminase (EC 3.5.5.5, Type 1, Sigma Chemical Co.) for 1 hour at room temperature, and then the substrate adenosine was added. Adenosine deamination was measured by the decrease in absorbance at $265 \mathrm{~nm}$ as a result of the conversion of adenosine to inosine.

\section{Results}

\section{Culture Characterization}

Whole cell analyses revealed the presence of the meso isomer of 2,6-diaminopimelic acid and the sugar madurose (3-O-methyl-D-galactose). The presence of meso DAP would classify the organism 
Table 1. Morphology and pigmentation of conidial chains and conidiophore, (14-day old culture) of Actinomadura sp. ATCC 39365.

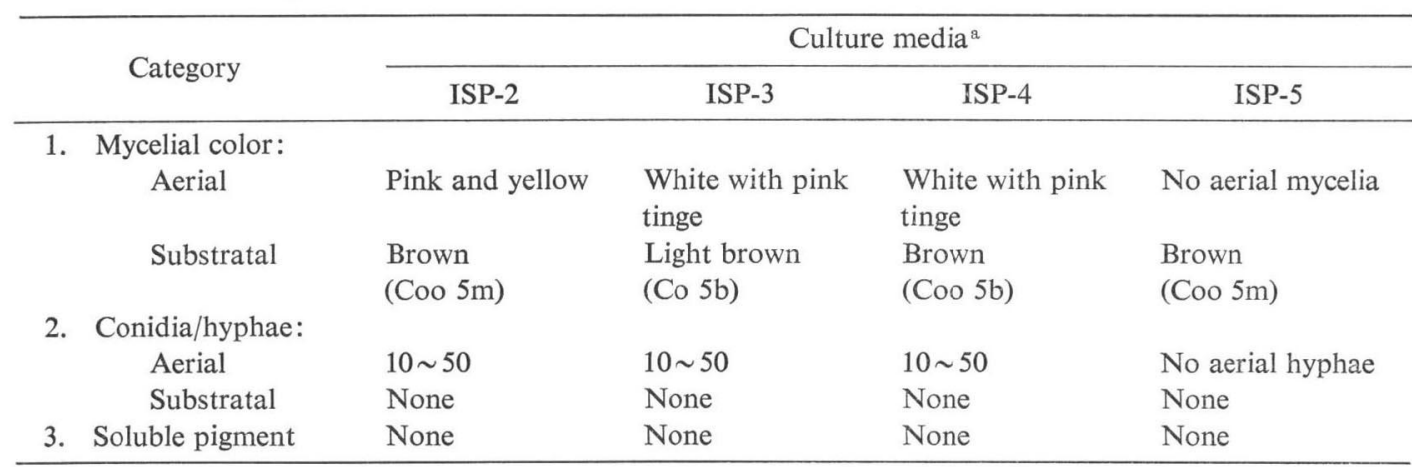

a ISP-2 (yeast extract - malt extract agar); ISP-3 (oatmeal agar); ISP-4 (inorganic salts - starch agar); ISP-5 (glycerol - asparagine agar).

Table 2. Carbon utilization pattern of Actinomadura sp. ATCC 39365.

\begin{tabular}{lc}
\hline Carbohydrate & Growth $^{\mathrm{a}}$ \\
\hline L-Arabinose & + \\
D-Fructose & + \\
D-Glucose & + \\
$i$-Inositol & \pm \\
D-Mannitol & - \\
Raffinose & + \\
L-Rhamnose & + \\
Sucrose & - \\
D-Xylose & + \\
Salicin & - \\
D-Galactose & - \\
\hline a + ; Good growth, - ; no growth, & \pm ; marginal \\
growth. &
\end{tabular}

Fig. 2. Electron micrograph of the spores of $A c$ tinomadura sp. ATCC 39365, 15,300 $\times(14$-day old culture on water agar).

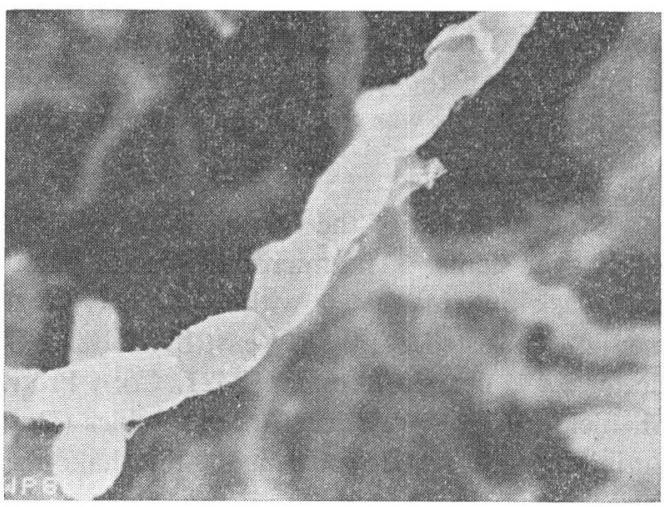

as cell wall chemotype III, and the presence of madurose would assign it to maduromycetes ${ }^{12)}$.

The spore chain morphology was characterized by single hooks. The organism reduced nitrate but did not liquefy gelatin nor coagulated milk; it did not produce melanin on peptone - yeast extract iron agar (ISP-6) or on tyrosine agar. Other morphological and physiological characteristics are shown in Table 1. The carbon utilization pattern is shown in Table 2.

The spore chain morphology produced in the aerial hyphae, in the form of hooks with no substrate spores, would further assign the organism under the genus Actinomadura. The spores were elliptical with smooth surface (Fig. 2).

\section{Fermentation}

The production of 2-CP in the 1,890-liter fermentor was observed 24 hours after inoculation (Fig. 3). The inhibitory zone diameter at the 24 -hour period was $42 \mathrm{~mm}$ vs. the assay organism, E. faecalis PD 05045. The peak production of the antibiotic was observed at the $112 \sim 120$-hour periods, with inhibitory zone of $54 \mathrm{~mm}$. The relationships of inhibitory zone and concentration of chloropentostatin is shown in Table 3.

The growth of the organism as measured by mycelial sedimentation $(15 \mathrm{ml}$ fermentation broth, 
Fig. 3. Fermentation pattern of Actinomadura sp. ATCC 39365.

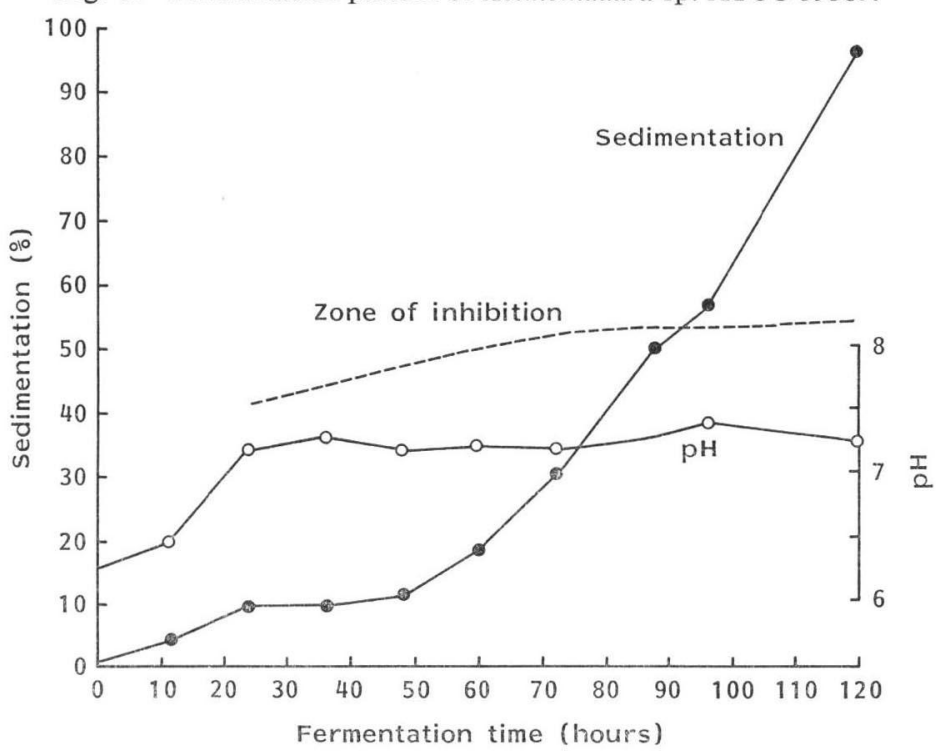

Table 3. Inhibitory zone of different concentrations of 2 -chloropentostatin vs. Enterococcus faecalis PD 05045.

\begin{tabular}{cc}
\hline Concentration $(\mu \mathrm{g} / \mathrm{ml})$ & Zone diameter $(\mathrm{mm})^{\mathrm{a}}$ \\
\hline 0.1 & 29 \\
0.2 & 40 \\
2.0 & 47 \\
20.0 & 55
\end{tabular}

a Paper disc diameter, $12.7 \mathrm{~mm}$.

centrifuged for 12 minutes at $450 \times g$, International Clinical Centrifuge) ranged from $5 \sim 15 \%$ until the 50-hour period; afterwhich there was a rapid increase in growth reaching $96 \%$ at the 120-hour period.

\section{Selectivity of $E$. faecalis PD 05045 for 2-CP}

The assay organism, E. faecalis PD 05045 was found resistant to a number of antibiotics, but was particularly sensitive to 2-CP (Table 4). This test organism when plated on the CM medium detected chloropentostatin level of as low as $0.005 \mu \mathrm{g} / \mathrm{ml}$. However, 2-CP was inactive
Table 4. Activity of different nucleoside and antitumor antibiotics vs. Enterococcus faecalis PD 05045 grown on the $2^{\prime}$-chloropentostatin assay medium.

\begin{tabular}{lcc}
\hline Antibiotic & $\begin{array}{c}\text { Inhibitory } \\
\text { zone } \\
\text { diameter } \\
(\mathrm{mm})\end{array}$ & $\begin{array}{c}\text { Concentration } \\
(\mu \mathrm{g} / \mathrm{ml})\end{array}$ \\
\hline Adriamycin & 15 & 50 \\
Amicetin & 18 & 100 \\
Angustmycin A & 0 & 100 \\
Azaserine & 14 & 100 \\
Coformycin & 54 & 10 \\
Cordycepin & 20 & 50 \\
Daunomycin & 16 & 50 \\
DON & 26 & 1.0 \\
Echinomycin & 20 & 1.0 \\
Formycin & 0 & 100 \\
Mithramycin & 21 & 1.0 \\
Mitomycin C & 14 & 1.0 \\
Puromycin & 18 & 50 \\
Sparsomycin & 0 & 100 \\
Streptozotocin & 17 & 20 \\
Tubercidin & 32 & 10 \\
Vidarabine & 0 & 1,000 \\
Pentostatin & 29 & 0.1 \\
Chloropentostatin & 29 & 0.1 \\
\hline
\end{tabular}

a Paper disc diameter, $12.7 \mathrm{~mm}$. vs. the same organism when grown in Trypticase soy agar (Difco).

Also, 2-CP was inactive vs. other microorganisms grown in complex assay media, e.g., Mycin assay agar and Penassay base agar (Difco). The organisms tested include: Alcaligenes viscolactis, Micrococcus luteus, Torulopsis albida, Bacillus subtilis, Agrobacterium tumefaciens. 
Fig. 4. ACKermann-Potter plot showing the inhibitory effect of chloropentostatin on the adenosine deaminase enzyme.

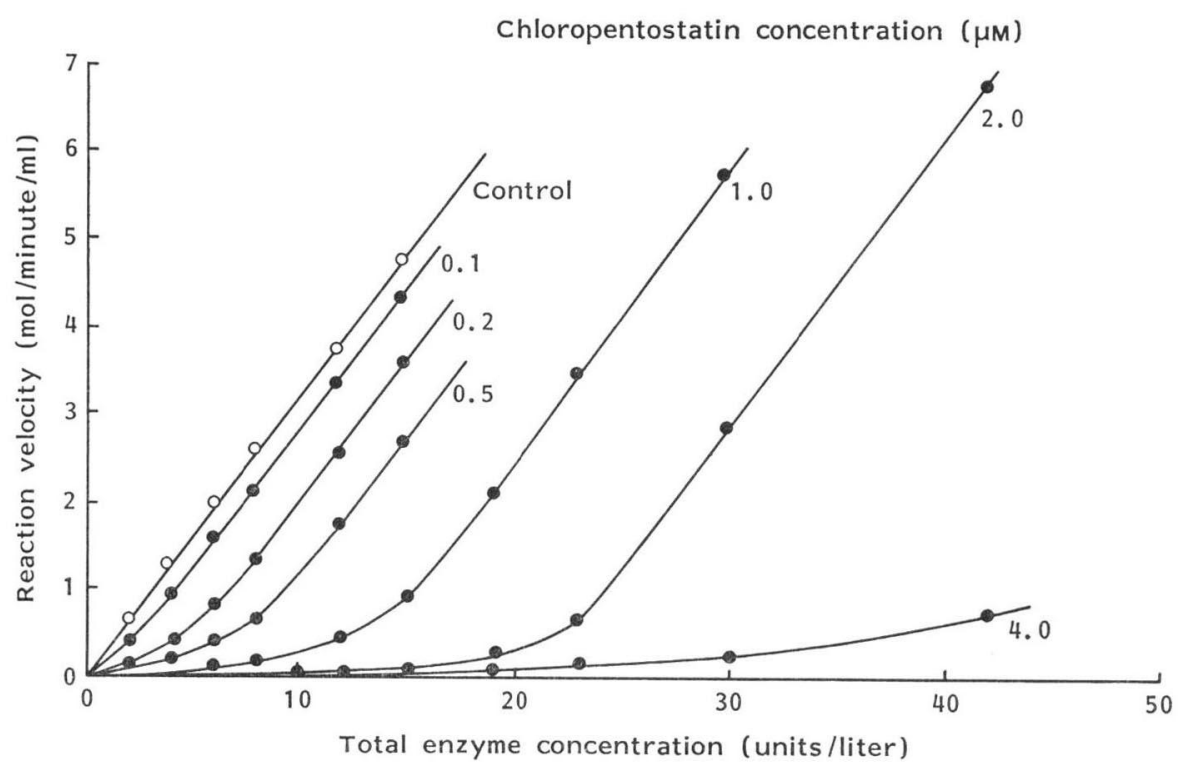

\section{Biochemical Activity}

The inhibitory effect of 2-CP on the adenosine deaminase enzyme was found to be stoichiometric or tight-binding. An Ackermann-PotteR ${ }^{13)}$ plot showing the stoichiometry of binding is shown in Fig. 4. The inhibitory potency $(K i)$ calculated according to the method of $\mathrm{CHA}^{14)}$, was $1.1 \times 10^{-10} \mathrm{M}$ (Borondy, P., unpublished data).

\section{Discussion}

2'-Chloropentostatin has been demonstrated to be a tight-binding adenosine deaminase (ADA) inhibitor in vitro, similar to pentostatin ${ }^{3)}$. Since the activity of ADA was found particularly high in acute lymphoblastic leukemia ${ }^{15)}$, the enzyme has served as a target for chemotherapy, particularly with pentostatin ${ }^{18)}$. The physiology of ADA binding to 2-CP in vivo has not been studied, which may present a subject for future investigation.

The antitumor activity of vidarabine against murine L1210 leukemia was found to be potentiated by pentostatin ${ }^{17}$. Preliminary data (LeOPOLD, W., personal communication) also indicated a chemotherapeutic synergy between vidarabine-5'-monophosphate and 2-CP, although additional studies need to be carried out to determine optimum dose combinations. In carrying out studies for optimum drug dosage and determining pharmacokinetics, quantitative assay systems are necessary to evaluate the levels and distribution of the compounds. Such assay system normally involves radiolabeled compounds. MCConNell et al. ${ }^{19)}$ and Suling et al. ${ }^{20)}$ circumvented the use of radiolabeled compounds by the use of microbiological assay systems for both vidarabine and pentostatin. E. faecalis PD 05045 plated in the CM assay medium offers a selective and very quantitative assay for 2-CP. Interestingly, when adenine in the assay medium is deleted, the sensitivity of the organism to 2-CP is reversed; the organism becomes selectively sensitive to vidarabine and resistant to 2-CP (unpublished data). Moreover, in the CM assay medium devoid of adenine, the presence of 2-CP increased the sensitivity of $E$. faecalis PD 05045 toward vidarabine. Thus, this assay medium could provide an in vitro system for optimizing 2-CP-vidarabine combinations for in vivo studies. 
Acknowledgment

This work was supported in part by the National Cancer Institute (USA); contract N01-CM-07379.

\section{References}

1) Dion, H. W.; P. W. K. Woo \& A. Ryder: Isolation and properties of a vidarabine deaminase inhibitor, co-vidarabine. Ann. N. Y. Acad. Sci. 284: 21 29, 1977

2) SCHABeL, F. M.: The antiviral activity of 9- $\beta$-D-arabinofuranosyladenine. Chemotherapy $13: 321 \sim$ 338,1968

3) Agarwal, R. P.; T. Spector \& R. E. Parks, Jr.: Tight-binding inhibitors. IV. Inhibition of adenosine deaminase by various inhibitors. Biochem. Pharmacol. 26: 359 367, 1977

4) Brink, J. J. \& G. A. LePAGE: Metabolism and distribution of 9- $\beta$-D-arabinofuranosyladenine in mouse tissues. Cancer Res. 24: 1042 1049, 1964

5) LePage, G. A.; L. S. Worth \& A. P. Kimball: Enhancement of the antitumor activity of arabinofuranosyladenine by 2'-deoxycoformycin. Cancer Res. 36: 1481 1485, 1976

6) Schaumberg, J. P.; G. C. Hokanson, J. C. French, E. Smal \& D. C. Baker: 2'-Chloropentostatin, a new inhibitor of adenosine deaminase. J. Org. Chem. 50: 1651 1656, 1985

7) Shirling, E. B. \& D. Gottlieb: Methods for characterization of Streptomyces species. Int. J. Syst. Bacteriol. 16: 313 340, 1966

8) Waksman, S. A.: The Actinomycetes. p. 194, Chronica Botanica Co., Waltham, Massachusetts, 1950

9) Hickey, R. J. \& H. D. Tresner: A cobalt-containing medium for the sporulation of Streptomyces species. J. Bacteriol. 64: 891 892, 1952

10) Becker, B.; M. P. Lechevalier \& H. A. Lechevalier: Chemical composition of cell wall preparations for strains of various form-genera of aerobic actinomycetes. Appl. Microbiol. 13: 236 243, 1965

11) Chassin, M. M.; R. H. Adamson, D. W. Zaharevitz \& D. G. Johns: Enzyme inhibition titration assay for 2 -deoxycoformycin and its application to the study of the relationship between drug concentration and tissue adenosine diaminase in dogs and rats. Biochem. Pharmacol. 28: 1849 1855, 1979

12) Goodfellow, M. \& S. T. Williams: Ecology of actinomycetes. Ann. Rev. Microbiol. 37: 189 216, 1983

13) Ackermann, W. W. \& V. R. Potter: Enzyme inhibition in relation to chemotherapy. Proc. Soc. Exp. Biol. Med. 72: 1 9, 1949

14) CHA, S.: Tight-binding inhibitors. I. Kinetic behavior. Biochem. Pharmacol. 24: 2177 2185, 1975

15) Smyth, J. F.; D. G. Poplack \& B. J. Holiman: Correlation of adenosine deaminase activity with cell surface markers in acute lymphoblastic leukemia. J. Clin. Invest. 62: 710 712, 1978

16) Mitchell, B. S.; C. Koller \& C. Mejias: Inhibition of adenosine deaminase by $2^{\prime}$-deoxycoformycin in acute lymphoblastic leukemia. J. Clin. Chem. Clin. Biochem. 17: 427 428, 1979

17) LePage, G. A.; L. S. Worth \& A. P. Kimball: Enhancement of the antitumor activity of arabinosyladenine by 2'-deoxycoformycin. Cancer Res. 36: 1481 1485, 1976

18) Whiteley, R. J.; B. C. Tucker, A. W. Kinkel, N. H. Barton, R. F. Pass, J. B. Whelchel, C. G. Cobbs, A. G. Diethelm \& R. A. Buchanan: Pharmacology, tolerance, and antiviral activity of vidarabine monophosphate in humans. Antimicrob. Agents Chemother. 18: 709 715, 1980

19) McConnell, W. R.; W. J. Suling, L. S. Rice, W. M. Shannon \& D. L. Hill: Use of microbiological and enzymatic assays in studies on the deposition of 2 -deoxycoformycin in the mouse. Cancer Treat. Rep. 62: 1153 1159, 1978

20) Suling, W. J.; L. S. Rice \& W. M. Shannon: Effects of 2'-deoxycoformycin and erythro-9-(2-hydroxy3 -nonyl)adenine on plasma levels and urinary excretion of $9-\beta$-D-arabinofuranosyladenine in the mouse. Cancer Treat. Rep. 62: 369 373, 1978

21) Ōmura, S.; N. Imamura, H. Kuga, H. Ishikawa, Y. Yamazaki, K. Okano, K. Kimura, Y. Takahashi \& H. TANAKA: Adechlorin, a new adenosine deaminase inhibitor containing chlorine. Production, isolation and properties. J. Antibiotics 38: 1008 1015, 1985 